\title{
MELATONIN DECREASES HEAT PRODUCTION IN FEMALE BROILER CHICKENS
}

\author{
M. ZEMAN ${ }^{1,2}$, J. BUYSE ${ }^{3}$, I. HERICHOVÁ ${ }^{2}$, E. DECUYPERE ${ }^{3}$ \\ ${ }^{1}$ Department of Animal Physiology and Ethology, Comenius University, \\ Bratislava, Slovakia \\ ${ }^{2}$ Institute of Animal Biochemistry and Genetics, Slovak Academy of Sciences, \\ Ivanka pri Dunaji, Slovakia \\ ${ }^{3}$ Laboratory for Physiology and Immunology of Domestic Animals, \\ Catholic University of Leuven, B-3 001 Heverlee, Belgium \\ Received September 22, 2000 \\ Accepted February 7, 2001

\section{Abstract}

Zeman, M., J. Buyse, J., I. Herichová, E. Decuypere: Melatonin Decreases Heat Production in Female Broiler Chickens. Acta Vet. Brno 2001, 70: 15-18.

The principal hormone of the pineal gland, melatonin, is involved in the control of circadian rhythms in birds. Moreover, several studies link melatonin with modulation of metabolism and growth in chickens. Therefore, the present study examines effects of pharmacological doses of melatonin on feed conversion and heat production in female broiler chickens. The supplementation of melatonin at a dose of $150 \mathrm{mg} / \mathrm{kg}$ of food increased plasma hormone levels to $28.76 \pm 0.47 \mathrm{ng} / \mathrm{ml}$ and $19.29 \pm 0.62 \mathrm{ng} / \mathrm{ml}$ in 14- and 21-day-old chickens, respectively. The treatment resulted in a highly significant decline in heat production of 2-week and 3-week-old chickens (8.38 and $13.05 \%$, respectively). Feed conversion was improved only in younger chickens. The present data are consistent with hypothesis that melatonin reduces heat production by lowering body temperature and regulating heat dissipation.

Poultry, feed conversion, energy metabolism, temperature

The pineal gland and its principal hormone melatonin play an important role in the circadian organisation in birds. Pineal melatonin synthesis is limited to the dark part of the light-dark cycle (Binkley 1988), the amplitude of the circadian melatonin rhythm is inversely related to length of photoperiod (Zeman and Illnerová 1988) and to some extent also to light intensity (Herichová et al. in preparation). In this way, plasma melatonin concentrations reflect environmental lighting conditions and transfer this information through the internal milieu to the entire organism.

Several studies link melatonin with modulation of metabolism and growth in chicken. Some studies (Osei et al. 1989) have shown that melatonin improves feed conversion but possible mechanisms of action are not understood. There are several levels at which melatonin may modulate efficiency of nutrient utilisation. This hormone can interact with transcriptional factors (Chuang et al. 1996) and growth hormone production (Zeman et al. 1999), modulate intermediary metabolism (Zeman et al. 1993), affect thermoregulatory mechanisms (Rozenboim et al. 1998) and influence energy metabolism (Apeldoorn et al. 1999).

The objectives of this experiment was to examine whether exogenous melatonin may influence heat production in broiler chickens.

\section{Materials and Methods}

Female Hybro broiler chickens $(n=22)$ were used for experiments. They were obtained as one-day old from a local hatchery (Euribrid, Aarschot, Belgium) and were raised on deep litter with free access to water and broiler

Address for correspondence:

Michal Zeman

Department of Animal Physiology and Ethology

84215 Bratislava, Slovakia
Phone: 0042176029642

Fax: 00421745943932

http://www.vfu.cz/acta-vet/actavet.htm 
feeding mash (23\% of crude protein and $13.6 \mathrm{MJ}$ of metabolizable energy per $\mathrm{kg}$ ). A near-continuous lighting schedule ( $23 \mathrm{~h}$ light $: 1 \mathrm{~h}$ dark) was used. Light intensity was 40-50 lux at chick's eye level.

At 2 weeks of age, 12 chickens were randomly taken from the floor pen and placed in pairs into 6 respiration chambers. Duration of the light period in chambers was the same as in the pen and intensity of light was in the range 20-30 lux. The temperature was kept at $26^{\circ} \mathrm{C}$. After an acclimatisation period of 2 days, birds were weighed, a known amount of control food was provided and oxygen consumption and $\mathrm{CO}_{2}$ production measurements were performed for the next 2 days. Following the control measurement, body weight and food consumption were recorded. Birds were provided with the same food but now supplemented with $150 \mathrm{mg} / \mathrm{kg}$ of melatonin (Sigma, St. Louis, USA). Again, $\mathrm{O}_{2}$ consumption and $\mathrm{CO}_{2}$ production were monitored for the next 2 days. After finishing the treatment, body weight and food consumption were recorded. Blood was collected from the brachial vein after the control and melatonin treatments for plasma melatonin measurements. Melatonin was determined by direct radioimmunoassay validated in our laboratory for using chicken plasma (Zeman et al. 1992). Two identical trials were conducted with 14- and 21-day-old birds (trials 1 and 2, respectively). Owing to technical failure only 10 birds were recorded in trial 2.

A detailed description of the open-circuit, indirect calorimeter unit used in our experiment is given elsewhere (Buyse et al. 1998). Briefly, this unit consists of 6 separation chambers for small animals $(550 \times 300 \times 500 \mathrm{~mm})$, equiped with a feeder and drinking nipple and a Pt-100 temperature sensor. The bottom consists of a wire mesh floor under which a tray can be placed for quantitative excreta collection. Fresh air enters the chamber trough a perforated stainless steel wall and leaves through the opposite wall. The air flow through each chamber is measured by a thermal mass flowmeter, dried and pumped to the Gas Analyser consisting of a infrared $\mathrm{CO}_{2}$ analyser and paramagnetic $\mathrm{O}_{2}$ analyser. Continuous readings of $\mathrm{CO}_{2}$ and $\mathrm{O}_{2}$ concentrations in fresh air (reference) and outlet chamber air, chamber temperature, air pressure are stored on a PC for subsequent heat production (HP) calculation. Each chamber was measured at 15 min intervals.

Heat production (HP) was calculated from $\mathrm{O}_{2}$ consumption and $\mathrm{CO}_{2}$ production according to the formula of Romijn and Lokhorst $(1961) \mathrm{HP}(\mathrm{kJ} / \mathrm{h})=19.18 \mathrm{O}_{2}(\mathrm{l} / \mathrm{h})+5.02 \mathrm{CO}_{2}(\mathrm{l} / \mathrm{h})$. Heat production was calculated per $\mathrm{kg}$ of metabolic body weight $\left(\mathrm{BW}^{0.75}\right)$ and expressed on a $24 \mathrm{~h}$ basis.

Statistical analysis

All results are expressed as means \pm SEM. Effect of melatonin treatment was analysed by paired $t$-test (SAS, 1986) comparing values from control and melatonin treatment for each respiration chamber.

\section{Results and Discussion}

Supplementation of melatonin at a dose of $150 \mathrm{mg} / \mathrm{kg}$ of food resulted in massive increase in melatonin concentrations in the circulation. Plasma melatonin concentrations in 14- and 21-day-old chickens $(\mathrm{n}=12)$ fed melatonin supplemented food exhibited $28.76 \pm 0.47 \mathrm{ng} / \mathrm{ml}$ and $19.29 \pm 0.62 \mathrm{ng} / \mathrm{ml}$, respectively. A trend to decreased concentrations of the hormone in older birds probably reflects an increase in body weight and higher "dilution" of fed melatonin. Both values are substantially higher than daytime melatonin concentrations measured in control birds $(0.10 \pm 0.01 \mathrm{ng} / \mathrm{ml})$. Nighttime melatonin concentrations ar usually more than 10-times higher than the levels measured during the daytime (Binkley 1988). It is clear that melatonin was administered at a pharmacological dose and therefore care must be taken in extrapolating experimental results to physiological conditions. However, the dose used was in the range used in published studies (Osei et al. 1989; Clark and Clas sen 1995) in which plasma melatonin concentrations were not measured and the absorption of this hormone into organism was not ascertained. Our data clearly showed that melatonin is well absorbed and remains stabile in broiler chicken when administrated in feed.

Experimental data on production parameters and heat production are summarised in Table 1. No significant differences in body weight gain (BWG) between melatonin and control birds were observed in trial 1 whereas in trial 2 a significant reduction in BWG after melatonin was observed. Similarly, no effect in trial 1 on feed intake, but a reduction of feed intake in trial 2 were observed. These resulted in opposite effects on feed conversion but we have to realise that these findings originated from very limited numbers of birds for production parameter.

The effect of dietary melatonin supplementation on heat production was similar and very pronounced in both trials. Supplementation of melatonin to the diet resulted in a highly significant $(P<0.001)$ decline in heat production of both, 2 - and 3 -week-old chickens when 
Table 1

Effect of melatonin on production parameters and heat production in female broiler chickens ( $\mathrm{n}=6$ and $\mathrm{n}=5$ for trial 1 and 2 , respectively).

\begin{tabular}{|c|c|c|c|c|c|c|}
\hline \multirow[b]{2}{*}{ Variable } & \multicolumn{2}{|c|}{$\begin{array}{c}\text { Trial } 1 \\
\text { 2-week-old }\end{array}$} & \multirow[b]{2}{*}{$P$} & \multicolumn{2}{|c|}{$\begin{array}{c}\text { Trial } 2 \\
\text { 3-week-old }\end{array}$} & \multirow[b]{2}{*}{$P$} \\
\hline & Control & Melatonin & & Control & Melatonin & \\
\hline $\begin{array}{l}\text { Body weight gain/ } \\
2 \mathrm{bird} / 24 \mathrm{~h}[\mathrm{~g}]\end{array}$ & $74 \pm 8$ & $86 \pm 6$ & NS & $130 \pm 7$ & $104 \pm 2$ & 0.017 \\
\hline $\begin{array}{c}\text { Feed intake/ } \\
2 \text { birds/ } 24 \mathrm{~h}[\mathrm{~g}]\end{array}$ & $121.7 \pm 12.5$ & $124.3 \pm 4.2$ & NS & $173.9 \pm 4.2$ & $166.0 \pm 3.1$ & 0.017 \\
\hline Feed conversion & $1.672 \pm 0.143$ & $1.306 \pm 0.040$ & 0.0405 & $1.350 \pm 0.062$ & $1.531 \pm 0.014$ & 0.0390 \\
\hline $\begin{array}{l}\text { Heat production/ } \\
\mathrm{kg} / 24 \mathrm{~h}\end{array}$ & $978 \pm 6$ & $892 \pm 7$ & 0.0006 & $830 \pm 11$ & $721 \pm 10$ & 0.0002 \\
\hline $\begin{array}{l}\text { Heat production/ } \\
\text { BW } 0.75 / 24 \mathrm{~h}\end{array}$ & $774 \pm 6$ & $734 \pm 6$ & 0.0088 & $748 \pm 8$ & $677 \pm 8$ & 0.0003 \\
\hline
\end{tabular}

expressed per kg of body weight. This decline represented $8.38 \%$ and $13.05 \%$, respectively. When heat production was expressed per metabolic body weight $\left(\mathrm{kJ} / \mathrm{d} / \mathrm{BW}^{0.75}\right)$ differences between control and melatonin treated chickens still remained highly significant.

The present data are consistent with a recent paper of A peld o orn et al. (1999) reporting that melatonin supplementation to a broiler diet reduces heat production, and more significantly, the physical activity related heat production. A decreased physical activity was recorded also in Japanese quail that were treated with melatonin in drinking water (Zeman et al. 1993). The declined physical activity of birds is in line with reports on sedative effects of melatonin (Forbes and Injidi 1979; Hishikaw a et al. 1969). In the present study no detailed behavioural observations were performed.

The decrease of heat production after melatonin treatment in chickens may explain improved feed conversion of chicken fed diet supplemented with this hormone as observed by Osei et al. (1989) and Clark and Clas sen (1995). The decline in heat production could be attributed to the hypothermic effect of melatonin (George 1982; 1999). A dosedependent reduction in basal temperature after a single melatonin injection was recorded also in chickens (Rozenboim et al. 1998). The heat production in their experiment rose during the first hour after melatonin injection and decreased in parallel to the decline of body temperature afterwards. The decreased basal temperature subsequently results in a lower dissipation of heat to environment (Rozen boim et al. 1998).

Recently, melatonin was suggested to be an effective scavenger of free radicals (Reiter 1995 ) and this action may be advantageous in broiler raising. A higher rate of free radicals formation, accompanying fast growth and intensive metabolism of broiler chickens, contributes to development of metabolic diseases, such as ascites and sudden death syndrome (Bottje and Wideman 1995). In this context, a lower intensity of metabolism, as reflected by lower $\mathrm{O}_{2}$ consumption in melatonin-treated birds, may lead to lower formation of free radicals and together with protective effects of melatonin may lower the incidence of above-mentioned diseases. The incidence of sudden death syndrome was numerically lower in melatonin treated chickens (Clark and Classen 1995) but more studies are needed to understand this problem. 


\section{Melatonin znižuje produkciu tepla u brojlerových kurčiat}

Dominantný hormón epifýzy, melatonín, sa zúčastňuje regulácie cirkadiánnych rytmov vtákov. Okrem toho viaceré štúdie spájajú úlohu tohto hormónu aj s moduláciou metabolizmu a rastu u kurčiat. Predkladaná práca preto analyzuje účinky farmakologických dávok melatonínu na konverziu krmiva a energetický metabolizmus u brojlerových kurčiat samičieho pohlavia. Pridanie melatonínu do krmiva v dávke 150 $\mathrm{mg} / \mathrm{kg}$ zvýšilo plazmatické koncentrácie tohto hormónu na 28,76 $\pm 0,47 \mathrm{ng} / \mathrm{ml} \mathrm{u} 14$ dňových a na 19,29 $\pm 0,62 \mathrm{ng} / \mathrm{ml}$ u 21 -dňových kurčiat. Aplikácia vyvolala vysoko signifikantné zníženie produkcie tepla u 14-dňových $(8,38 \%)$ i 21-dňových $(13,05 \%)$ kurčiat. Konverzia krmiva bola zlepšená iba pri mladších kurčatách. Získané údaje podporujú hypotézu, že melatonín znižuje produkciu tepla znížením telesnej teploty a znížením uvolňovaného tepla do prostredia.

\section{Acknowledgement}

This study was partially supported by grant of the Scientific Agency of Slovak Republic, VEGA (Nr. 2/1015/21).

\section{References}

APELDOORN E. J., SCHRAMA J. W., MASHALY, M. M., PARMENTIER, H. K. 1999: Effect of melatonin and lighting schedule on energy metabolism in broiler chickens. Poult Sci. 78: 223-229

BINKLEY, S. 1988: The pineal: endocrine and neuroendocrine function. Englewood Cliffs, NJ, Prentice Hall, pp. 246-261

BOTTJE, W. G., WIDEMAN, R. F. 1995: Potential role of free radicals in the pathogenesis of pulmonary hypertension syndrome. Poult. Avian Biol. Rev. 6: 211-231

BUYSE, J., MICHELS, H., VLOEBERGHS, J., SAEVELS, P.., AERTS, J. M., DUCRO, B., BERCKMANS, D., DECUYPERE, E. 1998: Energy and protein metabolism between 3 and 6 weeks of age of male broiler chickens selected for growth rate or for improved food efficiency. Br. Poult. Sci. 39: 264-272

CHUANG, J. I., MOHAN, N., MELTZ, M. L., REITER, R. J. 1996: Effect of melatonin on NF-kappa-B DNAbinding activity in the rat spleen. Cell Biol. Int. 20: 687-92

CLARK, W. D., CLASSEN, H. L. 1995: The effects of continuously or diurnally fed melatonin on broiler performance and health. Poult. Sci. 74: 1900-1904

FORBES, J. M., INJIDI, M. H. 1979: Feeding and sleeping in chickens following melatonin and triiodothyronine injections. J. Physiol. 296: 57P-58P

GEORGE, J. C. 1982: Thermogenesis in the avian body and the role of the pineal in thermoregulation. Prog. Clin. Biol. Res. 92: 217-231

GEORGE, J. C. 1999: Muscle, metabolism and melatonin. In: Melatonin in the promotion of health (R. R. Watson, Ed.) CRC Press, Boca Raton, pp. 69-97

HISHIKAWA, Y., CRAMER, H., KUHLO, W. 1969: Natural and melatonin-induced sleep in young chickens a behavioral and electrographic study. Exp. Brain Res. 7: 84-94

OSEI, P., ROBBINS, K. R., SHIRLEY, H. V. 1989: Effect of exogenous melatonin on growth and energy metabolism of chickens. Nutr. Res. 9: 69-81

REITER, R. J. 1995: The role of the neurohormone melatonin as a buffer against macromolecular oxidative damage. Neurochem Int. 27: 453-460

ROMIJN, C., LOKHORST, W. 1961: Some aspects of energy metabolism in birds. $2^{\text {nd }}$ Symposium on Energy metabolism. European Association for Animal Production. 10: 49-59

ROZEMBOIN, I., MIARA, L., WOLFENSON, D. 1998: The thermoregulatory mechanisms of melatonin-induced hypothermia in chicken. Am. J. Physiol. 274: R232-R236

ZEMAN, M., ILLNEROVÁ, H. 1988: Rapid adjustment of the pineal N-acetyltransferase rhythm to change from long to short photoperiod in the Japanese quail (Coturnix coturnix japonica). J. Pineal Res. 5: 565-571

ZEMAN, M., GWINNER, E., ŠOMOGYIOVÁ, E. 1992: Development of melatonin rhythm in the pineal gland and eyes of chick embryo. Experientia. 48: 765-765

ZEMAN, M., VÝBOH, P., JURÁNI, M., LAMOŠOVÁ, D., KOŠŤÁL, L', BILČÍK, B., BLAŽÍČEK, P., JURÁNIOVÁ, E. 1993: Effects of exogenous melatonin on some endocrine, behavioural and metabolic parameters in Japanese quail Coturnix coturnix japonica. Comp. Biochem. Physiol. 105: 323-328

ZEMAN, M., BUYSE, J., LAMOŠOVÁ, D., HERICHOVÁ, I., DECUYPERE, E. 1999: Role of melatonin in the control of growth and growth hormone secretion in poultry. Domest. Anim. Endocrinol. 7:199-207 